\title{
Prediction of intake in growing dairy heifers under tropical conditions
}

\section{A. S. Oliveira ${ }^{1}$ and V. B. Ferreira}

Instituto de Ciências Agrárias e Ambientais, Universidade Federal de Mato Grosso - Campus Sinop, Sinop, Mato Grosso, Brazil, 78557-267

\begin{abstract}
A meta-analysis was conducted to develop models of the prediction of dry matter intake (DMI) in growing dairy heifers [postweaning to $390 \mathrm{~kg}$ of body weight $(\mathrm{BW})]$ under tropical conditions. The adequacy of the models was assessed in a comparison with the 4 US models currently used to predict DMI [Quigley; National Research Council; and 2 Hoffman models]. The data set was created using 95 treatment means from 28 studies published in journals. The data set (studies) was randomly divided into 2 data subsets for the statistical analyses. The first data subset was used to develop the prediction equations for DMI (17 studies; 58 treatment means), and the second data subset was used to assess the adequacy of the predictive models (11 studies; 37 treatment means). The models were developed using nonlinear and linear mixed analyses. Breed (Bos taurus vs. Bos taurus $\times$ Bos indicus), BW $(240.2 \pm 62.2 \mathrm{~kg})$, and average daily gain (ADG, 0.83 $\pm 0.28 \mathrm{~kg} / \mathrm{d}$ ) were the independent variables. No significant effects of the breed or the interactions between the breed and metabolic $\mathrm{BW}\left(\mathrm{BW}^{0.75}\right)$ or breed and ADG were detected. Thus, nonlinear $[\mathrm{DMI}=0.1175$ $\left.\times \mathrm{BW}^{0.75}-3.4984 \times \mathrm{e}^{(-2.4690 \times \mathrm{ADG})}\right]$ and linear models $\left[\mathrm{DMI}=8.7147-0.2402 \times \mathrm{BW}^{0.75}+0.0027 \times\left(\mathrm{BW}^{0.75}\right)^{2}\right.$ $\left.+3.6050 \times \mathrm{ADG}-1.4168 \times \mathrm{ADG}^{2}\right]$ were proposed for both breeds. The nonlinear model explained $81 \%$ of the variation in the DMI, over-predicted the DMI by 0.21 $\mathrm{kg} / \mathrm{d}$ and predicted the DMI with a higher accuracy and precision than the linear model [root mean square error of prediction (RMSEP) $=8.82$ vs. $10.71 \%$ of the observed DMI, respectively]. The Quigley model explained only $54 \%$ of the variation in the DMI and was the fourth most accurate and precise model (RMSEP = $11.21 \%$ of the observed DMI). The National Research Council model explained $69 \%$ of the variation in the DMI but under-predicted the DMI by $0.53 \mathrm{~kg} / \mathrm{d}$, with an RMSEP of $12.72 \%$ of the observed DMI and presence of systematic constant bias. The Hoffman exponential
\end{abstract}

Received March 27, 2015.

Accepted October 25, 2015.

${ }^{1}$ Corresponding author: andresoli@ufmt.br model I (BW as the input) adequately predicted the DMI with an accuracy that was similar to the proposed nonlinear model. The equation of the Hoffman exponential model I explained $75 \%$ of the variation in the DMI and over-predicted the DMI by $0.07 \mathrm{~kg} / \mathrm{d}$, which was the second most accurate and precise equation (RMSEP $=9.35 \%$ of the observed DMI). However, the Hoffman exponential model II (BW and diet NDF as the inputs) did not adequately predict the DMI, because it explained only $54 \%$ of the variation in the DMI, under-predicted the DMI by $0.72 \mathrm{~kg} / \mathrm{d}$, and had a high RMSEP (17.96\% of the observed DMI). The use of nonlinear models increase the accuracy and the precision of the prediction of DMI compared with the linear models. Only the models proposed in the present study, the Hoffman exponential model I (BW as the input), and the Quigley model were adequate for the prediction of the DMI of growing dairy heifers under tropical conditions.

Key words: feed intake, meta-analysis, modeling

\section{INTRODUCTION}

The accurate prediction of feed intake by cattle is essential to optimize the use of nutrients and the productive, economic, and environmental performance of dairy cattle systems (Souza et al., 2014). However, the accurate estimation of the DMI remains a challenge. Because of the difficulty in the use of complex predictive DMI models with the accuracy and the simplicity necessary for the formulation and evaluation of diets, and despite the complexity of the mechanisms that regulate feed intake, several current predictive US models (Quigley et al., 1986; NRC, 2001; Hoffman et al., 2008) use empirical approaches to predict the DMI of dairy heifers with animal (i.e., BW and ADG) or diet variables as inputs (i.e., $\mathrm{NE}_{\mathrm{M}}$, TDN, and $\mathrm{NDF}$ ).

However, the application of empirical models is population-dependent, and the use of such models is limited to specific diets, animal breeds, and conditions of management and environment. Although US models are those used most commonly in Brazil to predict the DMI of dairy heifers, these models may lack the accuracy and the precision to predict the DMI under tropi- 
cal conditions because of the differences between the Brazilian and US dairy cattle systems, environmental conditions, genetic background of the heifers, and the typical species and nutritional composition of the forages. Therefore, we hypothesized that empirical models developed for tropical conditions would be more accurate and precise than the currently used US models.

Thus, our objectives were (1) to develop models (linear and nonlinear) to predict the DMI in dairy heifers under tropical conditions with BW and ADG as inputs, and (2) to evaluate and compare the adequacy of the proposed models with the current US models (Quigley et al., 1986; NRC, 2001; Hoffman et al., 2008) using an independent data set.

\section{MATERIALS AND METHODS}

\section{Data Set}

The data set used in the current study was developed from 28 studies (95 treatment means; 596 heifers postweaning) published in journals from 1999 to 2014. All journals cited are not included in the list of predatory journals compiled by Beall (2015). The criteria adopted for inclusion in the data set were: (1) the experiment was conducted under tropical conditions; (2) the heifers were under different feeding management systems and levels of production; (3) the animals did not receive milk or milk replacer; (4) the estimation of pasture intake was based only on external and internal markers to determine the fecal output of DM; and (4) the descriptions of the animals (e.g., BW, ADG, and breed) and the experimental diets (e.g., ingredients and chemical composition) were adequate. All studies used individual animal measurements. We did not find penbased intake studies.

Specifically, the data set was composed of the breeds Bos taurus $\times$ Bos indicus (78\%) and Bos taurus (22\%), which were fed either TMR $(82 \%)$ or pasture-based diets $(18 \%)$. The forages used for the TMR-fed heifers included sugarcane (Saccharum officinarum; 32.9\%), corn (Zea mays) silage (19.7\%), Bermudagrass hay (Cynodon spp.; 15.8\%), elephant grass (Pennisetum purpureum, Schum.) silage (13.2\%), sorghum silage (5.3\%), a mixture of corn silage and sugarcane or elephant grass silage (10.6\%), and a mixture of spineless cactus (Opuntia ficus-indica Mill.) and elephant grass silage $(2.5 \%)$. The forages grazed by the pasture-fed heifers included brachiaria grass (Brachiaria spp.; $82.3 \%$ ), mixture of pastures based on African stargrass (Cynodon nlemfuensis), ratana (Ischaemum indicum), and candelario (Pennisetum purpureum; 11.8\%), and ryegrass (Lolium multiflorum, Lam.) plus oats (Avena strygosa, Schreb.; 5.9\%).
The BW of the heifers was based only on measurements from nonfasting animals. Thus, in the studies that reported only fasting $\mathrm{BW}$, the $\mathrm{BW}$ was estimated by dividing the fasting BW by 0.96 (NRC, 2000). The data set was classified by breed (Bos taurus $\times$ Bos indicus crossbreed and Bos taurus). For statistical analyses, the data set was randomly divided into 2 data subsets, with the first data subset (17 studies; 58 treatment means; Table 1 and Appendix 1) used to develop the models to predict the DMI and the second data subset (11 studies; 37 treatment means; Table 1 and Appendix 2) used to assess the adequacy of the newly developed DMI prediction models in a comparison with the 4 currently available models (Table 2). The complete data set is available in an Excel (Microsoft Corp., Redmond, WA) file in Supplementary Tables S1 and S2 (http:// dx.doi.org/10.3168/jds.2015-9638).

\section{Model Development}

The linear and nonlinear models used to predict the DMI were adjusted with the inclusion of the metabolic BW $\left(\mathbf{B W}^{0.75}\right), \mathrm{ADG}$, and breed (Bos taurus vs. Bos taurus $\times$ Bos indicus) as fixed effects and the study as a random effect. Because the data set was developed using observations from several studies in which different feeding systems, environmental conditions, and experimental methodologies were used, it was necessary to quantify the variance associated with the study and to predict the fixed effects adjusted for the study effect. Therefore, each study in the data set was treated as a random sample from the larger population of studies (St-Pierre, 2001; Sauvant et al., 2008).

All the parameter coefficients for the linear model were estimated using the linear mixed procedure (StPierre, 2001). The nonlinear mixed (i.e., NLMIXED) procedure (Littell et al., 2006) was used to fit the nonlinear models for the prediction of the DMI. The Gauss-Newton method was used for the convergence. The critical level of probability for a type I error was set at $\alpha=0.05$. If the interactions breed $\times \mathrm{BW}^{0.75}$ and breed $\times$ ADG were not significant $(P>0.05)$, they were excluded from the models.

\section{Model Evaluation}

The adequacy of the 2 DMI predictive proposed models and of the current US models (Table 1) were assessed for precision and accuracy using the following approaches: graphic analysis, linear regression of the observed and the predicted values, coefficient of determination, mean square error of prediction (MSEP), root MSEP (RMSEP), and concordance correlation coefficient (CCC) analysis using the Model Evaluation 
Table 1. Descriptive statistics of the data sets used to develop and evaluate the models to predict the DMI of growing dairy heifers

\begin{tabular}{|c|c|c|c|c|c|c|}
\hline Item & Mean & Median & Maximum & Minimum & $\mathrm{SD}$ & $\mathrm{n}$ \\
\hline Development $^{1}$ & & & & & & \\
\hline Forage diet, $\%$ of DM & 61.08 & 60.00 & 100.00 & 23.24 & 19.36 & 54 \\
\hline NDF diet, $\%$ of DM & 49.02 & 45.08 & 81.08 & 30.70 & 12.60 & 47 \\
\hline TDN diet, $\%$ of DM & 65.65 & 67.64 & 84.30 & 47.19 & 9.10 & 26 \\
\hline $\mathrm{NE}_{\mathrm{M}}$ diet, ${ }^{2} \mathrm{Mcal} / \mathrm{kg}$ of DM & 1.49 & 1.56 & 2.07 & 0.87 & 0.30 & 26 \\
\hline DMI, $\mathrm{kg} / \mathrm{d}$ & 6.36 & 6.56 & 10.68 & 2.63 & 1.99 & 58 \\
\hline Forage diet, $\%$ of DM & 58.72 & 61.94 & 83.4 & 10.0 & 20.22 & 28 \\
\hline $\mathrm{NDF}$ diet, $\%$ of $\mathrm{DM}$ & 66.46 & 64.85 & 77.50 & 58.59 & 9.24 & 21 \\
\hline $\mathrm{CP}$ diet, $\%$ of $\mathrm{DM}$ & 14.08 & 13.81 & 17.50 & 12.08 & 1.38 & 31 \\
\hline TDN diet, $\%$ of $\mathrm{DM}$ & 66.46 & 64.85 & 77.50 & 58.59 & 9.24 & 21 \\
\hline $\mathrm{NE}_{\mathrm{M}}$ diet, $^{2} \mathrm{Mcal} / \mathrm{kg}$ of $\mathrm{DM}$ & 1.52 & 1.47 & 1.87 & 1.26 & 0.17 & 21 \\
\hline DMI, $\mathrm{kg} / \mathrm{d}$ & 6.57 & 6.33 & 9.50 & 3.88 & 1.24 & 37 \\
\hline
\end{tabular}

${ }^{1}$ Appendix 1 and Supplementary Table S1 (http://dx.doi.org/10.3168/jds.2015-9638).

${ }^{2}$ Estimated as NRC (2001) from TDN diet. $\mathrm{NE}_{\mathrm{M}}=1.37 \times\left(\mathrm{ME}\right.$ for $\left.\mathrm{NE}_{\mathrm{G}}\right)-0.138 \times\left(\mathrm{ME} \text { for NE } \mathrm{N}_{\mathrm{G}}\right)^{2}+0.0105 \times(\mathrm{ME} \text { for NE })^{3}-1.12$, where $\mathrm{ME}$ for $\mathrm{NE}_{\mathrm{G}}(\mathrm{Mcal} / \mathrm{kg}$ of $\mathrm{DM})=0.82 \times \mathrm{DE} \operatorname{diet}(\mathrm{Mcal} / \mathrm{kg}$ of $\mathrm{DM})$, and DE diet $(\mathrm{Mcal} / \mathrm{kg}$ of DM $)=\operatorname{observed~TDN~diet~}(\% \mathrm{DM}) \times 0.04409$.

${ }^{3}$ Appendix 2 and Supplementary Table S2 (http://dx.doi.org/10.3168/jds.2015-9638).

System (College Station, TX; http://nutritionmodels. tamu.edu/mes.html) as described by Tedeschi (2006).

The RMSEP values were expressed relative to the observed means. The MSEP was composed of 3 sources of error: (1) the error caused by bias, (2) the error caused by the deviation of the regression slope from 1 , and (3) the random error. The random error was the error that was not explained by the model (Bibby and Toutenburg, 1977). The precision and accuracy of the DMI prediction models were assessed by estimating the CCC, as described by Lin (1989). The CCC was divided into a correlation coefficient $(\boldsymbol{\rho})$ and a precision and bias correction factor $\left(\mathbf{C}_{\mathbf{b}}\right)$ for accuracy. The $\rho$ and $\mathrm{C}_{\mathrm{b}}$ values range from 0 to 1 , with values closer to 1 indicating more precision and accuracy (Lin, 1989; King and Chinchilli, 2001; Liao, 2003). Additionally, the Kolmogorov-Smirnov D test (Kolmogoroff, 1933; Smirnov,
1933) was used to assess the probability whether the 2 data sets (e.g., observed and predicted values) had the same distribution.

\section{RESULTS AND DISCUSSION}

The data subsets that were used to develop and to evaluate the DMI prediction models represented a wide range of dairy heifer types and diet characteristics, but the data were specific to growing heifers (postweaning to $390 \mathrm{~kg}$ of BW). No studies were found with heifers with a BW that exceeded $390 \mathrm{~kg}$. The descriptive statistics for the heifers and the diets used in the 2 data subsets were similar, which indicated that the subsets were adequately randomized (Table 1 ). Moreover, the breeds were representative of the dairy cattle systems commonly used in Brazil (Stock et al., 2007).

Table 2. Models to predict the DMI $(\mathrm{kg} / \mathrm{d})$ of growing dairy heifers

\begin{tabular}{|c|c|}
\hline Model & Equation $^{1}$ \\
\hline Quigley et al. (1986) & $\begin{array}{l}\mathrm{DMI}=-29.86-0.0000154 \times \mathrm{BW}^{2}+0.157 \times \mathrm{BW}^{0.75}+2.09 \times \mathrm{ADG}-0.118 \times \mathrm{ADG}^{2}+0.73 \times \mathrm{TDN}-0.0048 \\
\times \mathrm{TDN}^{2}-0.0014 \times \mathrm{BW} \times \mathrm{ADG}-0.019 \times \mathrm{TDN} \times \mathrm{ADG}\end{array}$ \\
\hline NRC (2001) & $\mathrm{DMI}=\left[\mathrm{BW}^{0.75} \times\left(0.2435 \times \mathrm{NE}_{\mathrm{M}}-0.0466 \times \mathrm{NE}_{\mathrm{M}}^{2}-0.1128\right) / \mathrm{NE}_{\mathrm{M}}\right]$ \\
\hline $\begin{array}{l}\text { Exponential } 1 \\
\text { Exponential II }\end{array}$ & 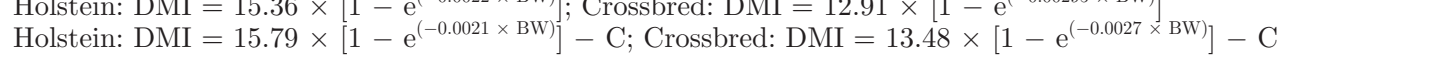 \\
\hline Proposed models & 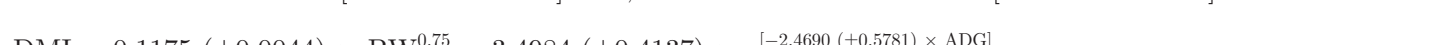 \\
\hline
\end{tabular}


The interactions $(P>0.05)$ of breed $\times \mathrm{BW}^{0.75}$ and breed $\times$ ADG were not significant $(P>0.05)$. Thus, a nonlinear model $\left[\mathrm{DMI}=0.1175 \times \mathrm{BW}^{0.75}-3.4984\right.$ $\left.\times e^{(2.4690 \times \mathrm{ADG})}\right]$ and a linear model $[\mathrm{DMI}=8.7147-$ $0.2402 \times \mathrm{BW}^{0.75}+0.0027 \times\left(\mathrm{BW}^{0.75}\right)^{2}+3.6050 \times$ $\left.\mathrm{ADG}-1.4168 \times \mathrm{ADG}^{2}\right]$ were proposed for both breeds (Table 2). The model equations to predict the DMI included the $\mathrm{BW}^{0.75}$ and the $\mathrm{ADG}$ as independent variables because of the theoretical relationship of these factors with the regulation of energy intake.

The composition of the diets was not included as a fixed effect in the models for 2 primary reasons. (1) The dietary variables correlated with the gut fill (i.e., the indigestible and the potentially digestible NDF and the rates of passage and degradation) and with the regulation of metabolic intake (i.e., energy density, rumen degradability of starch, rumen degradability of protein, and amount and type of fat) were not reported in sufficient detail in the studies selected for the current meta-analysis. Likewise, (2) according to the NRC (2001), the most common approach to formulate dairy cattle diets is to establish the nutrient requirements and the predicted DMI before the determination of dietary ingredients.

Heat stress negatively affects the performance of animals (West, 2003). When the environmental conditions are outside the thermal neutral zone because of increased air temperature and the temperature-humidity index, the DMI, growth, and feed efficiency decrease substantially. Thus, an adjustment for the environmental conditions should be required for the accurate prediction of the DMI. However, because the reported environmental data were insufficient in the studies selected for the current meta-analysis, the climate variables (e.g., air temperature and temperature-humidity index, among others) were not used as fixed effects in the models.

The proposed nonlinear model was discrete, with more accuracy and precision to predict DMI than proposed linear model (Table 3; Figure 1). Although the bias of the nonlinear model was higher (over-prediction of $0.21 \mathrm{~kg}$ of $\mathrm{DMI} / \mathrm{d}$ ) than of the linear model (overprediction of $0.02 \mathrm{~kg}$ of DMI/d), it had lower RMSEP (8.82 vs. $10.71 \%$ of the observed DMI) and higher precision ( $\rho=0.90$ vs. 0.82 ).

The proposed nonlinear model was discrete, with more accuracy and precision to predict DMI than Quigley et al. (1986) or Hoffman et al. (2008) model I (Table 3; Figure 1). For the nonlinear model, the intercept between the observed and the predicted DMI was not different from zero and the slope was not different from unity $(P=0.08)$. This equation explained $81 \%$ of the variation in the DMI, with the lowest bias in the RMSEP ( $8.82 \%$ of the observed DMI) and the largest participation $(86.1 \%)$ of the random error in the RMSEP, which indicated that most of the model error was

Table 3. Summary of statistical measures to assess the adequacy of several models using regression between observed (Y) and model predicted (X) DMI values

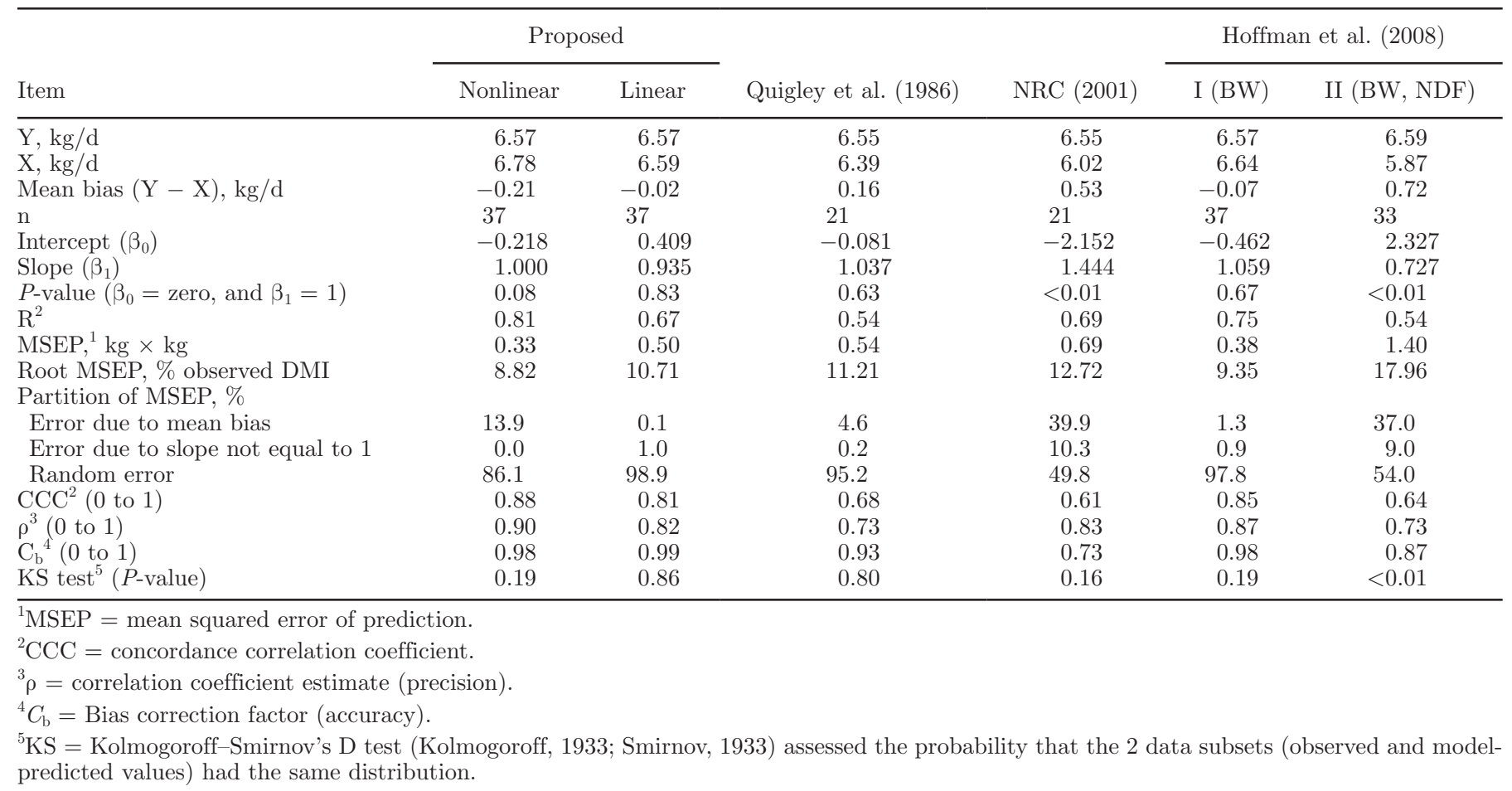



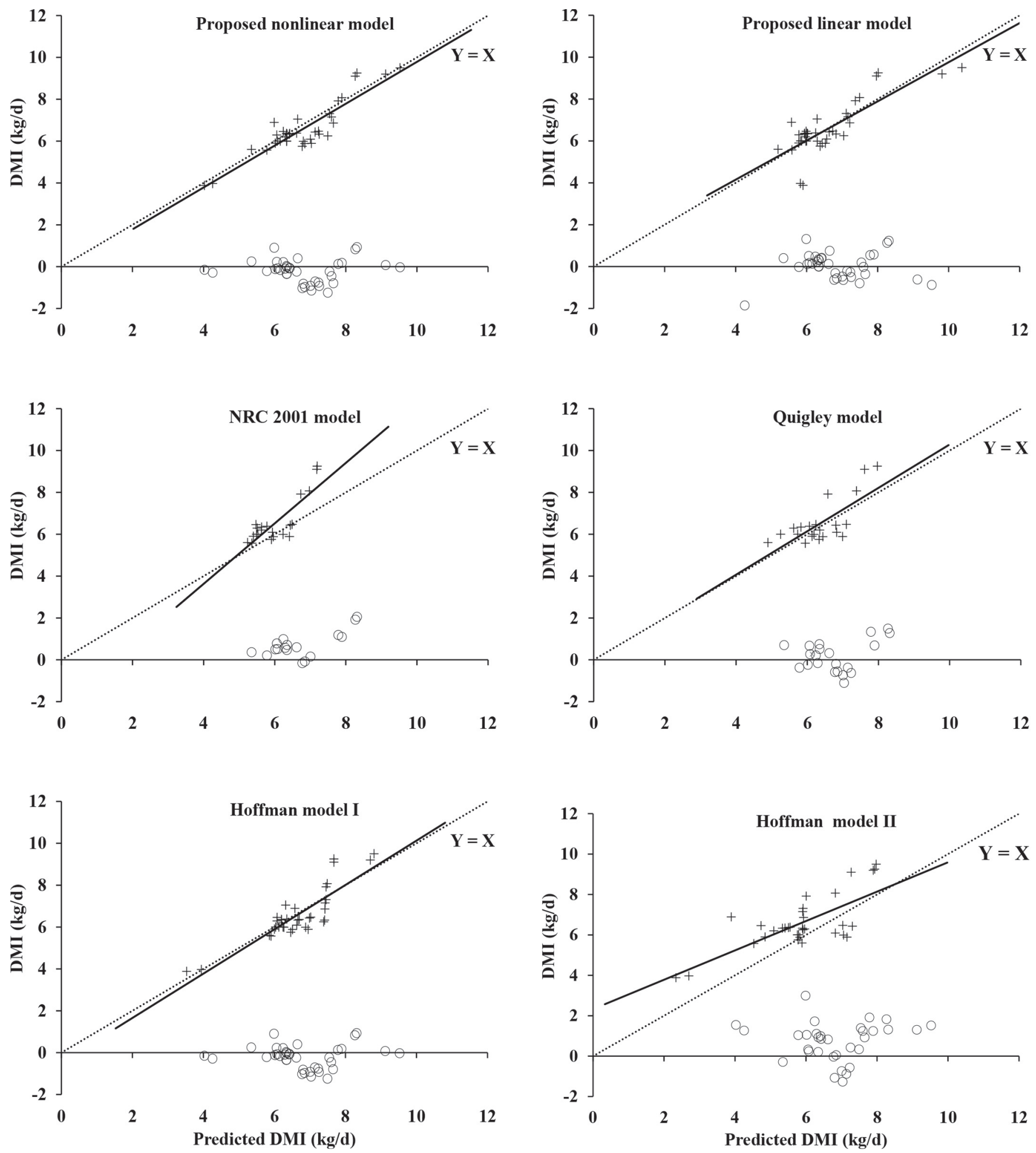

Figure 1. Relationship between observed (squares) and residual (observed - predicted; circles) DMI values, with predicted values for growing dairy heifers using the proposed models (nonlinear and linear) using NRC (2001), Quigley et al. (1986), and Hoffman et al. (2008) models (I = $\mathrm{BW}$ as input; and II = BW and diet NDF as inputs). 
not associated with the fixed variables. Additionally, the proposed nonlinear model resulted in the highest precision $(\rho=0.90)$ and accuracy $\left[\mathrm{C}_{\mathrm{b}}=0.98\right.$; similar to linear model and Hoffman et al. (2008) model I], which reinforced the robustness of the model to predict the DMI of dairy heifers under tropical conditions.

The new nonlinear equation to predict the DMI was probably more adequate than the other models because of 2 major factors. (1) The data used to develop the new model for DMI predictions were obtained from heifers raised in the tropics and the environment, the breeds, and the nutritional composition of the forages are different between the Brazilian and the US dairy cattle systems; therefore, the effects of the animal variables (i.e., BW and $\mathrm{ADG}$ ) on the DMI of heifers are also different. (2) The study was used as a random effect in the model, which improves the predictions in biological systems and provides a more accurate description of the prediction errors (St-Pierre, 2001).

The Quigley et al. (1986) model adequately predicted the DMI with an accuracy that was similar to the proposed linear model. The intercept between the observed and the predicted DMI was not different from zero and the slope was not different from unity $(P=0.63)$. The equation explained only $54 \%$ of the variation in the DMI, but under-predicted the DMI by $0.16 \mathrm{~kg} / \mathrm{d}$ and was the fourth most accurate equation for predicting DMI; the RMSEP was $11.21 \%$ of the observed DMI, and $\mathrm{C}_{\mathrm{b}}$ was 0.93 (Table 3; Figure 1). However, the precision was lower than proposed nonlinear and linear models and Hoffman et al. (2008) model I. The Quigley et al. (1986) equation was developed from 182 twenty-eightday DMI measurements of feeding trials with US growing dairy heifers (100-400 kg of BW) in confinement housing. Despite the differences in the environmental and dietary conditions between Brazil and the United States, the Quigley et al. (1986) model was adequate to predict the DMI in dairy heifers under tropical conditions, likely because of the incorporation of the TDN diet as an input (in addition to the BW and the ADG). Thus, the model attempted to account for the physical and metabolic controls on intake (Conrad et al., 1964).

The NRC (2001) model did not adequately predict the DMI. The intercept between the observed and the predicted DMI was different from zero and the slope was different from unity $(P \leq 0.01)$. This equation explained $69 \%$ of the variation in the DMI, the DMI was under-predicted by $0.53 \mathrm{~kg} / \mathrm{d}$, and it had low accuracy $\left(\mathrm{C}_{\mathrm{b}}=0.73\right)$, with an RMSEP of $12.72 \%$ of the observed DMI and a large participation $(39.9 \%)$ of error due to mean bias, which indicated systematic constant bias (Table 3; Figure 1). The NRC (2001) model adopted the beef heifer DMI equation (NRC, 2000) and used the $\mathrm{NE}_{\mathrm{M}}$ diet and the $\mathrm{BW}^{0.75}$ as inputs (Table 2). The
$\mathrm{NE}_{\mathrm{M}}$ diet was obtained by division between $\mathrm{NE}_{\mathrm{M}}$ and DMI (NRC, 2001). Silva (2011) observed that the $\mathrm{NE}_{\mathrm{M}}$ used by the NRC (2001) of $86 \mathrm{kcal} / \mathrm{kg}$ of $\mathrm{BW}^{0.75}$ was $13 \%$ lower than the $\mathrm{NE}_{\mathrm{M}}$ measured in a respirometric chamber for crossbred or Holstein dairy heifers. Thus, the underestimation of the $\mathrm{NE}_{\mathrm{M}}$ for dairy heifers under tropical conditions might be the cause of the DMI underestimation with the NRC (2001) model. Additionally, the differences between Brazilian and US dairy cattle systems, environmental conditions, genetic background of the heifers, and the nutritional composition of the forages might explain some of the variability in the NRC (2001) model used for Brazilian heifers.

For the 2 exponential Hoffman et al. (2008) models, the levels of accuracy and precision for the prediction of the DMI were different. Hoffman et al. (2008) exponential model I (BW as the input) adequately predicted the DMI with accuracy similar to the proposed nonlinear model. This equation explained $75 \%$ of the variation in the DMI, over-predicted the DMI by $0.07 \mathrm{~kg} / \mathrm{d}$, and was the second most accurate and precise equation for the prediction of the DMI, with an RMSEP of $9.35 \%$ of the observed DMI and the $\rho$ and $\mathrm{C}_{\mathrm{b}}$ values of 0.87 and 0.98 , respectively (Table 3; Figure 1). However, Hoffman et al. (2008) exponential model II (BW and diet NDF as the inputs) did not adequately predict the DMI. The intercept was different from zero and the slope was different from unity $(P<0.01)$, which indicated a poor relationship between the observed and the predicted DMI (Table 3; Figure 1). This model explained only $54 \%$ of the variation in the DMI, under-predicted the DMI by $0.72 \mathrm{~kg} / \mathrm{d}$, and had a high RMSEP $(17.96 \%$ of the observed DMI) and a low precision $(\rho=0.73)$. The incorporation of the diet NDF into Hoffman et al. (2008) exponential model II reduced the quality of the prediction, probably because differences between quality of NDF-forage tropical (present data set) and NDF-forage nontropical [used for Hoffman et al. (2008) model II]. The quality of the NDF is highly variable because of the physical and chemical differences between NDF sources (i.e., potentially digestible NDF, indigestible NDF, and rate of digestion and rate of passage), which limits the use of only the diet NDF as input to DMI predictive models (Oliveira et al., 2011).

\section{CONCLUSIONS}

The use of nonlinear models increase the accuracy and the precision of the predictions of DMI for growing dairy heifers compared with the linear models. The incorporation of diet NDF as an input reduced the quality of the DMI prediction based on Hoffman et al. (2008) exponential model II. The NRC (2001) model and Hoffman et al. (2008) exponential model 
II are not recommended to predict the DMI of growing dairy heifers under tropical conditions. Only the models proposed in the present study, Hoffman et al. (2008) exponential model I (with BW as the input), and the Quigley et al. (1986) model can adequately predict the DMI of growing dairy heifers (postweaning to $390 \mathrm{~kg}$ of BW). Futures studies should incorporate to empirical model dietary variables correlated with gut fill (i.e., indigestible and potentially digestible NDF, rates of passage and degradation), with regulation of metabolic intake (i.e., energy density, rumen degradability of starch, rumen degradability of protein, and amount and type of fat), and with climate variables (e.g., air temperature and temperature-humidity index, among others) to improve the prediction of the intake of heifers raised in tropical conditions.

\section{ACKNOWLEDGMENTS}

The authors thank Fundação de Amparo à Pesquisa do Estado de Mato Grosso (FAPEMAT, project number 483724/2011 PRONEM 006/2011), Conselho Nacional de Desenvolvimento Científico e Tecnológico (CNPq, Brazil; Projects numbers 305826/2013-1 and 207300/2014-3), Coordenação de Aperfeiçoamento de Pessoal de Nível Superior (CAPES) and Universidade Federal de Mato Grosso - Campus Sinop for finantial support.

\section{REFERENCES}

Beall, J. 2015. Scholarly open-access: Critical analysis of scholarly open-access publishing. Accessed Jul. 9, 2015. http://scholarlyoa. com/publishers/

Bibby, J. D., and H. Toutenburg. 1977. Prediction and Improved Estimation in Linear Models. John Wiley \& Sons, Berlin, Germany.

Conrad, H. R., A. D. Pratt, and J. W. Hibbs. 1964. Regulation of feed intake in dairy cows. 1. Change in importance of physical and physiological factors with increasing digestibility. J. Dairy Sci. $47: 54-62$.

Hoffman, P. C., K. A. Weigel, and R. M. Wernberg. 2008. Evaluation of equations to predict dry matter intake of dairy heifers. J. Dairy Sci. 91:3699-3709.

King, T. S., and V. M. Chinchilli. 2001. Robust estimator of the concordance correlation coefficient. J. Biopharm. Stat. 11:83-105.

Kolmogoroff, A. N., 1933. Sulla determinazione empirica di una legge di distribuzione. Giornale dell'Istituto Italiano degli Attuari 4:8391.

Liao, J. J. Z. 2003. An improved concordance correlation coefficient. Pharm. Stat. 2:253-261.

Lin, L. I. K. 1989. A concordance correlation coefficient to evaluate reproducibility. Biometrics 45:255-268.

Littell, R. C. G. A., W. W. Milliken, R. D. Stroup, R. D. Wolfinger, and O. Schabenberger. 2006. SAS for Mixed Models. 2nd ed. SAS Institute, Cary, NC.

NRC. 2000. Nutrient Requirements of Beef Cattle. 7th rev. ed. Natl. Acad. Sci., Washington, DC.

NRC. 2001. Nutrient Requirements of Dairy Cattle. 7th rev. ed. Natl. Acad. Sci., Washington, DC.

Oliveira, A. S., E. Detmann, J. M. S. Campos, D. S. Pina, S. M. Souza, and M. G. Costa. 2011. Meta-analysis of the impact of neutral de- tergent fiber on intake, digestibility and performance of lactating dairy cows. Rev. Bras. Zootec. 40:1587-1595.

Quigley, J. D., R. E. James, and M. L. Mcgilliard. 1986. Dry matter intake in dairy heifers. 2. Equations to predict intale of heifers under intensive management. J. Dairy Sci. 69:2863-2867.

Sauvant, D., P. Scmidely, J. J. Daudin, and N. R. St-Pierre. 2008. Meta-analyses of experimental data: Application in animal nutrition. Animal 2:1203-1214.

Silva, R. R. 2011. Respirometria e determinação das exigências de energia e produção de metano de fêmeas bovinas leiteiras de diferentes genótipos. PhD Thesis. University Federal of Minas Gerais., Belo Horizonte, Brazil.

Smirnov, N. 1933. Estimate of deviation between empirical distribution functions in two independent samples. Moscow Univ. Math. Bull. 2:3-16.

Souza, M. C., A. S. Oliveira, C. V. Araújo, A. F. Brito, R. M. A. Teixeira, E. H. B. K. Moares, and D. C. Moura. 2014. Short communication: Prediction of intake in dairy cows under tropical conditions. J. Dairy Sci. 97:3845-3854.

St-Pierre, N. R. 2001. Invited review: Integrating quantitative findings from multiple studies using mixed model methodology. J. Dairy Sci. 84:741-755.

Stock, L. A., A. V. Carneiro, G. R. Carvalho, R. Zoccal, P. C. Martins, and L. C. T. Yamaguchi. 2007. Brazilian milk production systems and its representativeness. Accessed May 27, 2013. http://www. cileite.com.br/sites/default/files/sistemas_de_producao_e_sua_ representatividade_na_producao_de_leite_no_brasil.pdf.

Tedeschi, L. O. 2006. Assessment of the adequacy of mathematical models. Agric. Syst. 89:225-247.

West, J. W. 2003. Effects of heat-stress on production in dairy cattle. J. Dairy Sci. 86:2131-2144.

\section{APPENDIX 1}

\section{List of Publications Describing the Experiments Used in the Development Model}

Almeida Júnior, G. A. A., C. Costa, S. M. R. Carvalho, P. Persochetti Júnior, and A. Panichi. 2008. Performance of Holstein calves fed after weaning with high moisture grains silage or dry ground grains of corn or sorghum. Rev. Bras. Zootec. 37:148-156.

Carvalho, M. C., M. A. Ferreira, C. V. A. Cavalcanti, L. E. Lima, F. M. Silva, K. F. Miranda, A. S. C. Véras, M. Azevedo, and V. C. F. Vieira. 2005. Association of sugar cane bagasse, forage cactus and urea with different supplements in diets of Holstein heifers. Acta Sci. Anim. Sci. 27:247-252.

Costa, P. B., A. C. Queiroz, M. T. Rodrigues, A. L. R. Magalhães, M. G. Costa, F. L. B. Toral, T. A. Carvalho, L. Monteiro, K. Zorzi, and M. S. Duarte. 2007. Performance of dairy heifers on a compensatory growth regime supplemented with monensin. Rev. Bras. Zootec. 36:461-470.

Dias, A. M., F. F. Silva, C. M. Veloso, L. C. V. Ítavo, A. J. V. Pires, D. R. Souza, J. F. Sá, F. B. L. Mendes, and P. V. Nunes Nascimento. 2008. Cassava bagasse in diets of dairy heifers: Intake of nutrients and productive performance. Arq. Bras. Med. Vet. Zootec. 60:987-995.

Mendes Neto, J., J. M. S. Campos, S. C. Valadares Filho, R. P. Lana, A. C. Queiroz, R. and F. Euclydes. 2007. Chewing activity of dairy heifers fed diets with partial replacement of Tifton 85 hay with citrus pulp. Rev. Bras. Zootec. 36:618-625.

Mendonça, B. P. C., R. P. Lana, A. B. Mancio, E. Detmann, A. M Barbosa, and G. Guimarães. 2010. Levels of mineral mixture and urea in supplementation of crossbred heifers, with Gyr predominance, reared at pasture during the dry season. Rev. Bras. Zootec. 39:2273-2280.

Mota, D. A., T. T. Berchielli, R. C. Canesin, B. L. Rosa, A. F. Ribeiro, and H. V. Brandt. 2013. Nutrient intake, productive performance and body measurements of dairy heifers fed with different sources of protein. Acta Sci. Anim. Sci. 35:273-279. 
Oliveira, M. C. M., R. P. Lana, E. C. Eifert, D. F. Luz, and F. M. Vargas Junior. 2009. Performance of Holstein heifers in feedlot receiving monensin at different levels. Rev. Bras. Zootec. 38:1835-1840.

Pereira, J. C., D. N. F. V. Cunha, P. R. Cecon, and E. S. Faria. 2008. Performance, rectal temperature and respiratory ratio of dairy heifers from three genetic groups fed diets with different levels of fiber. Rev. Bras. Zootec. 37:328-334.

Pereira, J. C., P. R. C. Silva, P. R. Cecon, M. A. Resende Filho, and R. L. Oliveira. 2003. Broiler-litter and supplement based on ruminal microbiota in dairy heifers diets: Performance and economic evaluation. Rev. Bras. Zootec. 32:653-662.

Pereira, L. M. R., V. Fischer, C. B. Moreno, E. X. Ferreira, R. M. P. Pardo, J. F. Gomes, and P. L. Monks. 2005. Energy-protein supplementation on body development of grazing jersey heifers. Rev. Bras. Zootec. 34:175-187.

Rangel, A. H. N., J. M. S. Campos, A. S. Oliveira, S. C. Valadares Filho, A. J. Assis, and S. M. Souza. 2010. Performance and nutritional parameters of growing heifers fed corn silage or sugar cane with concentrate. Rev. Bras. Zootec. 39:2518-2526.

Rocha Neto, A. L., C. M. Veloso, F. F. Silva, D. R. Menezes, H. C. Oliveira, S. T. Azevedo, A. A. Pinheiro, A. C. Oliveira, L. T. Costa, D. R. Souza. 2010. Economic evaluation of the confinement of dairy heifers fed cocoa meal in the diet. Rev. Bras. Saúde Prod. An. 11: 1068-1080.

Siécola Júnior, S., L. L. Bitencourt, L. Q. Melo, V. A. Silveira, N. M. Lopes, J. R. M. Silva, R. A. N. Pereira, and M. N. Pereira. 2014. Deleafed sugarcane and performance of heifers and dairy cows. Arq. Bras. Med. Vet. Zootec. 66:219-228.

Silva, F. F., M. S. M. A. Aguiar, C. M. Veloso, A. J. V. Pires, P. Bonomo, G. S. Dutra, V. S. Almeida, G. G. P. Carvalho, R. R. Silva, A. M. Dias, and L. C. V. Ítavo. 2006. Performance of dairy heifers fed on elephantgrass silage added with different levels of cassava bagasse. Arq. Bras. Med. Vet. Zootec. 58:205-211.

Souza, A. L., R. Garcia, F. S. Bernardino, J. M. S. Campos, S. C. Valadares Filho, L. S. Cabral, and K. F. Gobbi. 2006. Coffee hulls in dairy heifers diet: Intake, digestibility, and production. Rev. Bras. Zootec. 35:921-927.

Teixeira, F. A., F. F. Silva, P. Bonomo, A. J. V. Pires, P. V. N. Nascimento, and J. G. Neto. 2014. Performance of dairy heifers grazing on Urochloa decumbens pastures deferred for two periods. Acta Sci. Anim. Sci. 36:109-115.

\section{APPENDIX 2}

\section{List of Publications Describing the Experiments Used in the Evaluation Models}

Farias, M. S., I. N. Prado, M. V. Valero, F. Zawadzki, R. R. Silva, C. E. Eiras, D. C. Rivaroli, and B. S. Lima. 2012. Glycerine lev- els for crossbred heifers growing in pasture: performance, feed intake, feed eficiency and digestibility. Semina. Ciências Agrárias. 33:1177-1188.

Macêdo, G. A. R., J. J. Ferreira, J. R. M. Ruas, E. L. Costa, F. M. Freire, and J. F. Pires. 2009. Performance of heifers fed with sugarcane varieties RB83-5486 and RB86-7515, with and without irrigation. Supplement e568 in Proc. 50th Annual Meeting of the Brazilian Society of Animal Science, Universidade Estadual de Maringá, Maringá.

Maciel, R. P., J. N. M. Neiva, V. L. Araujo, O. F. R. Cunha, J. Paiva, J. Restle, C. Q. Mendes, and R. N. B. Lôbo. 2012. Intake, nutrient digestibility and performance of dairy heifers fed diets containing palm kernel cake. Rev. Bras. Zootec. 41:698-706.

Maquivar, M. G., C. S. Galina, J. R. Galindo, S. Estrada, R. Molina, and G. P. Mendoza. 2010. Effect of protein supplementation on reproductive and productive performance in Bos indicus $\times$ Bos taurus heifers raised in the humid tropics of Costa Rica. Trop. Anim. Health Prod. 42:555-560.

Miranda, L. F., A. C. Queiroz, S. C. V. Filho, P. R. Cecon, E. S. Pereira, M. F. Paulino, J. M. S. Campos, and J. R. Miranda. 1999. Performance and ponderal development of dairy heifers fed sugar cane based diets. Rev. Bras. Zootec. 28:605-613.

Monteiro, C. C. F., A. A. S. Melo, M. A. Ferreira, J. M. S. Campos, J. S. R. Souza, E. T. S. Silva, R. P. X. Andrade, and E. C. Silva 2014. Replacement of wheat bran with spineless cactus (Opuntia ficus indica Mill cv. Gigante) and urea in the diets of Holstein x Gyr heifers. Trop. Anim. Health Prod. 46:1149-1154.

Queiroz, A. C., J. S. Neves, L. F. Miranda, E. S. Pereira, J. C. Pereira, and A. R. Dutra. 2001. Effect of fiber level and protein source on live weight gain of crossbred Holstein-Zebu heifers. Arq. Bras. Med. Vet. Zootec. 53:89-93.

Ribeiro, M. D., J. C. Pereira, R. A. M. Vieira, B. M. Pacheco, and F. P. Leonel. 2005. Intake and production of heifers at pasture supplemented with different levels of rumen undegradable protein. Rev. Bras. Zootec. 34:2486-2495.

Roma Júnior, L. C., H. Savastano Júnior, L. S. Martello, P. R. Leme, and M. G. Pinheiro. 2008. Veal production from crossbred and Holstein dairy calves. Rev. Bras. Zootec. 37:1088-1093.

Santos, S. A., J. M. S. Campos, S. C. Valadares Filho, A. S. Oliveira, S. M. Souza, and A. M. F. Santiago. 2010. Productive performance of growing dairy heifers fed corn silage and soybean or cottonseed meal based concentrate. Rev. Bras. Zootec. 39:638-647.

Teixeira, R. M. A., J. M. S. Campos, S. C. Valadares Filho, A. S. Oliveira, A. J. Assis, and D. S. Pina. 2007. Intake, digestibility and performance of dairy heifers fed coffee hulls replacing of corn silage. Rev. Bras. Zootec. 36:968-977. 